\title{
Clinician and patient barriers to the recognition of insomnia in family practice: a narrative summary of reported literature analysed using the theoretical domains framework
}

\author{
Rowan P. Ogeil ${ }^{1,2^{*}}$ (D), Samantha P. Chakraborty ${ }^{3}$, Alan C. Young ${ }^{4}$ and Dan I. Lubman ${ }^{1,2}$
}

\begin{abstract}
Background: Insomnia is a common sleep complaint, with 10\% of adults in the general population experiencing insomnia disorder, defined as lasting longer than three months in DSM-5. Up to 50\% of patients attending family practice experience insomnia, however despite this, symptoms of insomnia are not often screened for, or discussed within this setting. We aimed to examine barriers to the assessment and diagnosis of insomnia in family practice from both the clinician and patient perspective.

Methods: The present article identified research that has examined barriers to assessing insomnia from the clinician's and the client's perspectives following MEDLINE and Google Scholar searches, and then classified these barriers using the theoretical domains framework.

Results: The most common barriers from the clinician's perspective were related to Knowledge, Skills, and the Environmental Context. From the patient perspective, barriers identified included their Beliefs about the consequences of Insomnia, Social Influences, and Behavioural Regulation of Symptoms.

Conclusions: Utilising this theoretical framework, we discuss options for bridging the gap between the identification and subsequent management of insomnia within the family practice setting. To assist clinicians and those in community health care to overcome the Knowledge and Skills barriers identified, this article provides existing relevant clinical criteria that can be utilised to make a valid diagnosis of insomnia.
\end{abstract}

Keywords: Insomnia, Family practice, Clinician-factors, Patient-factors, Theoretical domains framework

\section{Background}

Chronic insomnia (ICSD-3) or insomnia disorder (DSM-5) is characterised by poor sleep quality or inadequate sleep, lasting for $>3$ months, accompanied by impaired daytime functioning $[1,2]$. Insomnia is common, affecting up to 1 in 3 adults in the UK [3], North America [4], Europe [5], and Australia [6], with an estimated $10 \%$ of the population suffering from chronic insomnia symptoms [7, 8]. Insomnia

\footnotetext{
* Correspondence: rowan.ogeil@monash.edu

${ }^{1}$ Eastern Health Clinical School and Monash Addiction Research Centre, Monash University, Melbourne, Australia

${ }^{2}$ Turning Point, Eastern Health, 110 Church St, Richmond, Victoria 3121 Australia

Full list of author information is available at the end of the article
}

has negative effects on the health and quality of life of an individual [9]. Insomnia is also associated with a substantial economic burden to the community $[10,11]$, estimated to exceed $\$ 63$ billion in the United States alone [12]. This burden includes not only health and direct medical-related costs, but costs due to lost productivity and/or errors attributable at work, or while driving that are attributable to sleep loss [13].

Insomnia is one of the most commonly encountered sleep disorders by clinicians in family practice (general practice in some jurisdictions) [14]. A recent study suggests that prevalence of insomnia complaints may be increasing, with up to $50 \%$ of patients who present to

(c) The Author(s). 2020 Open Access This article is distributed under the terms of the Creative Commons Attribution 4.0 International License (http://creativecommons.org/licenses/by/4.0/) which permits unrestricted use, distribution, and reproduction in any medium, provided you give appropriate credit to the original author(s) and the source, provide a link to the Creative Commons license, and indicate if changes were made. The Creative Commons Public Domain Dedication waiver (http://creativecommons.org/publicdomain/zero/1.0/) applies to the data made available in this article, unless otherwise stated. 
family practice suffering from insomnia [15]. Few patients presenting with insomnia to general practitioners (GPs) receive a referral for non-drug treatment, despite these treatments having the highest level of evidence for effectiveness [16]. Furthermore, the consequences of chronic insomnia are often not discussed by clinicians and patients in this setting [17-19].

Whilst there is a strong body of evidence demonstrating the importance of sleep to overall health and wellbeing, and literature devoted to treatment pathways for patients with insomnia within primary care [20, 21], studies have demonstrated that practitioners within this setting are often not assessing insomnia, or are uncertain regarding making the diagnosis [22]. Reasons for this may include factors associated with the primary care environment or physician and include: time pressure especially during initial consultations [23, 24], workload [25], and knowledge including potential uncertainty regarding the diagnoses of insomnia symptoms compared with other sleep disturbances $[19,26,27]$, which may interact to impair professional decision-making [28].

Alternatively, patient-related factors may hamper accurate assessment of insomnia complaints. Indeed, patients with insomnia symptoms may not always volunteer information about sleep to their physician without prompting [18]. This may be compounded in chronic insomnia cases, or be masked by a comorbid disorder including depression, anxiety or chronic pain. For example, Bartlett and colleagues [6] estimated that in $75 \%$ of cases where patients indicated insomnia was a problem for $>12$ months, only $11.1 \%$ had discussed their insomnia with their physician during the previous year. To date, there has been limited research examining barriers to seeking assistance for insomnia from the patient perspective.

Given the importance of identifying and managing insomnia, this paper examines barriers to the assessment and diagnosis of insomnia from both the clinician and patient perspective, applying the Theoretical Domains Framework, given that it provides a synthesising architecture, allowing for relevant summaries of behavioural barriers and facilitators to promote progress and facilitate shared understanding [29]. Such a frame is useful given that successful behavioural and public health interventions are based on an understanding of the contexts in which they occur [30], and unlike other frameworks, the TDF includes social and environmental factors as areas for examination of relevant barriers and facilitators.

\section{The theoretical domains framework (TDF)}

The Theoretical Domains Framework (TDF) was developed following collaboration of behavioural and implementation scientists who identified theories relevant to informing behaviour change, and grouped these constructs into domains in order to identify influences on the behaviour of health professionals in the implementation of evidence-based recommendations. The TDF has been widely used to examine challenges to the implementation of best practice within health care settings, having been cited $>800$ times [31]. For example, the TDF has been used to examine: factors hindering nurses and midwives from engaging with pregnant women about stopping smoking [32]; barriers to the implementation of good hand hygiene practices [33]; and retrospectively to understand barriers in family practice faced by both clinicians and patients. For example, Yamada et al. [34] identified barriers for physicians, allied health workers, and patients in their adherence to treatment for asthma. The present paper utilises the TDF in a qualitative, and retrospective manner, to examine barriers to assessing insomnia from both the clinician and patient perspective.

\section{Methods}

\section{Literature search and study identification}

Articles examining barriers to the detection of insomnia in family practice were reviewed, and grouped according to whether they represented 'clinician' or 'patient' factors. MEDLINE and Google Scholar databases were utilised to identify relevant articles, with no restriction placed on publication date. Articles were identified using combinations of the following key search terms: insomnia, family practice, general practice, and sleep disturbance. In addition to using keyword searches, the databases were used to identify papers that had cited relevant articles identified in keyword searches. Reference lists of identified articles were also examined to identify other relevant literature. Only articles reporting original data, and published in English were included. Articles that specifically considered barriers to the assessment and diagnosis of insomnia from either the clinician and/or patient were considered, rather than those reporting prevalence data only. Using this approach, 19 articles were identified for subsequent analysis.

A narrative rather than systematic approach was used in the present analysis given that we were interested in using the TDF to identify behavioural barriers reported in studies, rather than aggregating results of these previous studies systematically [35].

\section{Application of the TDF framework to identified studies}

Following study identification, we used the TDF as a framework in order to provide a theoretical lens through which to examine affective, cognitive, environmental and social influences affecting the identification of insomnia from the clinician and client perspectives within family practice [36]. This was done using Version 2 of the framework, where the relative domains have undergone validation, and as such we used the definitions and component constructs provided [33]. 
Each study was reviewed as to the relevant domains of the TDF providing the barrier to the recognition and/or assessment of insomnia in family practice. These include: 'knowledge', 'skills', 'social/professional role/identity', 'beliefs about capabilities', 'optimism' 'beliefs about consequences', 'reinforcement', 'intentions', 'goals', 'memory, attention and decision processes', 'environmental context and resources', 'social influences', 'emotion', and 'behavioural regulation' [30, 33].

\section{Results}

\section{Clinician factors}

Multiple barriers impact on a physician's ability to identify and assess insomnia (see Table 1). Applying the TDF to these barriers demonstrates that these most commonly fall on the following domains: Knowledge, Skill, and Environmental Context and Resources. These barriers include a lack of physician awareness of the negative physical and mental health impacts associated with insomnia, as well as limited training opportunities to develop expertise with sleep problems [17].

Many family practitioners have described their knowledge of sleep disorders and treatment options as 'fair' to 'poor', particularly in the areas of sleep physiology and sleep architecture [22]. Whilst being able to detect that a person was having problems with their sleep, physicians reported difficulty in defining the underlying cause and/ or identifying the correct treatment [22].

\section{Patient factors}

Research considering insomnia diagnoses within family practice clinics have primarily considered the proportion of patients suffering from insomnia and likely co-morbid risk factors; patient's reasons for seeking treatment; and their utilisation of particular treatments (see Table 2).

\section{Discussion \\ Clinician factors}

The present analysis has demonstrated that insomnia is encountered by those in family practice at a greater rate than that in the general population. This disparity likely represents general practitioners being the gatekeepers to further medical care [18]. Despite this role, there are substantial barriers to the recognition and diagnosis of insomnia. Using the TDF, we found from the clinician perspective that there are barriers related to: Knowledge or an awareness that insomnia is a significant issue in many cases, and/or a lack of training to identify insomnia as distinct from other sleep disorders. These barriers likely reflect a lack of education being included in training curriculum [9, 42, 44], and a lack of access to continuing education and professional development for primary care physicians [27, 47]. For example, Mindell and colleagues [47] reported that the average time spent on sleep tuition in medical school across countries was $2.5 \mathrm{~h}$, with some countries (e.g. Malaysia, Indonesia, Vietnam) providing no formal education, and only three countries (Australia, Canada, and the United States) providing more than $3 \mathrm{~h}$ of education. The lack of education around sleep disorders can have dire clinical consequences. For example, Lu et al. [48] found that a third of patients attending a sleep clinic were suffering from obstructive sleep apnea (OSA), but had been prescribed a sedative to help them sleep, inadvertently increasing their risk of having a motor vehicle accident.

While education of physicians has been demonstrated to improve sleep knowledge [40], the present article has identified that many in family practice rate their knowledge as either 'fair' or 'poor' and that there are gaps in their knowledge when assessing insomnia [22, 41]. Summarising the core features of sleep that contribute to a diagnosis of insomnia provides a useful and informative resource for those in family practice [17] (see Table 3).

The present analysis demonstrates that the primary care environment itself makes it difficult for general practitioners to assess sleep. Clinicians are often 'time poor' during consultations, may be presented with a lengthy list of complaints, and/or be reluctant to address sleep complaints [18], especially if they are rated as less important than other symptoms [53]. For example, in the UK, it is estimated that only $50 \%$ of patients with insomnia seek help from their general practitioner, with patients often receiving only a sleep hygiene leaflet or a hypnotic [42], which may have limited efficacy in treating their insomnia compliant [54], or be ignored by patients [45].

The timing of any insomnia assessment by a physician is also important given that chronic insomnia is unlikely to resolve on its own [21]. For example, previous studies have examined whether physicians assess sleep history during an initial consultation [19]. However, this initial meeting contains a myriad of priorities including the development of rapport and trust, learning about the patient and establishing the seriousness of any sleep-related complaints, all within time constraints. Hence, it may be difficult for a family practitioner to establish what constitutes a normal or impaired quantity and quality of sleep in new patients [55]. To date, limited studies have examined how general practitioner's diagnose sleep in their regular patients, which is important given the chronic nature of the disorder, and that the recommended treatment (e.g., $\mathrm{CBTi})$ may require multiple consultations and/or referral to a sleep specialist $[16,21]$.

\section{Patient factors}

From a patient perspective, different barriers were identified including the Beliefs about Consequences, in this case that insomnia symptoms are associated with poorer outcomes. However, an important finding of the present 
Table 1 Studies of general practitioners: measures and outcomes relating to insomnia

\begin{tabular}{|c|c|c|c|c|c|}
\hline $\begin{array}{l}\text { Authors } \\
\text { (Year) [Ref] } \\
\end{array}$ & $\begin{array}{l}\text { Country (community/ } \\
\text { cohort) }\end{array}$ & Study population & Measures & Main findings & TDF Domain(s) \\
\hline $\begin{array}{l}\text { Orr et al. } \\
\text { (1980) [37] }\end{array}$ & United States & $\begin{array}{l}378 \text { Physicians attending a } \\
\text { course on sleep disorders }\end{array}$ & $\begin{array}{l}\text { Examination of popular } \\
\text { misconceptions of sleep } \\
\text { (20 Questions) }\end{array}$ & $\begin{array}{l}\text { Physicians scored below chance } \\
\text { suggesting a greater need for sleep } \\
\text { medicine education as part of } \\
\text { training. }\end{array}$ & Skills \\
\hline $\begin{array}{l}\text { Hohagen } \\
\text { et al. (1993) } \\
\text { [38] }\end{array}$ & Germany & $\begin{array}{l}2512 \text { patients attending } 10 \\
\text { general practitioners }\end{array}$ & $\begin{array}{l}\text { Questionnaire at } 3 \text { time } \\
\text { points: baseline }(\mathrm{T} 1), 4 \\
\text { months later }(\mathrm{T} 2), 2- \\
\text { years later }(\mathrm{T} 3), \text { included } \\
\text { DSM criteria }\end{array}$ & $\begin{array}{l}\text { In } 8.8 \% \text { of cases of mild insomnia, } \\
21.9 \% \text { of cases of moderate } \\
\text { insomnia and } 39.2 \% \text { of cases of } \\
\text { severe insomnia the GP was aware } \\
\text { of a sleep problem. } 5 \% \text { of insomnia } \\
\text { cases were diagnosed without the } \\
\text { patient reporting a sleep problem } \\
\text { in the questionnaire. }\end{array}$ & $\begin{array}{l}\text { Knowledge, } \\
\text { Skills }\end{array}$ \\
\hline $\begin{array}{l}\text { Hohagen } \\
\text { et al. (1994) } \\
\text { [39] }\end{array}$ & Germany & $\begin{array}{l}330 \text { older adults (aged 65+) } \\
\text { attending } 5 \text { general } \\
\text { practitioner clinics }\end{array}$ & DSM-III-R criteria & $\begin{array}{l}\text { In } 18 \% \text { of cases of mild insomnia, } \\
31 \% \text { of cases of moderate insomnia } \\
\text { and in } 52 \% \text { of cases of severe } \\
\text { insomnia the GP was aware of a } \\
\text { sleep problem. } 14 \% \text { of insomnia } \\
\text { cases were diagnosed without the } \\
\text { patient reporting a sleep problem } \\
\text { in the questionnaire. }\end{array}$ & $\begin{array}{l}\text { Knowledge, } \\
\text { Skills }\end{array}$ \\
\hline $\begin{array}{l}\text { Haponik } \\
\text { et al. (1996) } \\
{[40]}\end{array}$ & United States & $\begin{array}{l}20 \text { experienced primary care } \\
\text { practitioners, } 23 \text { uninstructed } \\
\text { medical interns and } 22 \\
\text { interns with instruction on } \\
\text { sleep medicine }\end{array}$ & $\begin{array}{l}\text { Frequency of sleep } \\
\text { history recorded during } \\
\text { encounters with } \\
\text { simulated patients ( } 30 \\
\text { min consultations) }\end{array}$ & $\begin{array}{l}\text { Interns who had received } \\
\text { instruction in sleep medicine more } \\
\text { often asked about sleep ( } 81.8 \%) \text {, } \\
\text { but uninstructed interns }(13 \%) \text { and } \\
\text { physicians }(0 \%) \text { did not record } \\
\text { sleep history during consultation. }\end{array}$ & $\begin{array}{l}\text { Knowledge, } \\
\text { Belief about } \\
\text { capability }\end{array}$ \\
\hline \multirow[t]{2}{*}{$\begin{array}{l}\text { Papp et al. } \\
(2002)[41]\end{array}$} & \multirow[t]{2}{*}{$\begin{array}{l}\text { United States } \\
\text { (Northeast Ohio) }\end{array}$} & \multirow[t]{2}{*}{105 physicians } & \multirow[t]{2}{*}{$\begin{array}{l}\text { Structured survey on } \\
\text { attitudes and knowledge } \\
\text { of sleep disorders }\end{array}$} & $\begin{array}{l}\text { Physicians rated their knowledge of } \\
\text { sleep disorders as 'fair' (60\%) and } \\
\text { 'poor' ( } 30 \%) \text {. Only } 10 \% \text { rated their } \\
\text { knowledge as good, and } 0 \% \text { rated } \\
\text { it as excellent. }\end{array}$ & \multirow[t]{2}{*}{$\begin{array}{l}\text { Knowledge, } \\
\text { Skills, } \\
\text { Professional } \\
\text { Role and } \\
\text { Identity, }\end{array}$} \\
\hline & & & & $\begin{array}{l}\text { Greatest influence on changing } \\
\text { practice style regarding sleep were } \\
\text { journal articles followed by } \\
\text { continuing education, followed by } \\
\text { discussion with specialists. }\end{array}$ & \\
\hline \multirow[t]{2}{*}{$\begin{array}{l}\text { Siriwardena } \\
\text { et al. (2010) } \\
{[42]}\end{array}$} & \multirow[t]{2}{*}{$\begin{array}{l}\text { United Kingdom } \\
\text { (Lincolnshire, rural } \\
\text { cohort) }\end{array}$} & \multirow[t]{2}{*}{$\begin{array}{l}\text { Cross-sectional study of GPs } \\
(n=84)\end{array}$} & \multirow[t]{2}{*}{$\begin{array}{l}\text { Prescribing preferences } \\
\text { of GPs for insomnia vs } \\
\text { anxiety diagnoses }\end{array}$} & $\begin{array}{l}\text { For insomnia, GPs were more likely } \\
\text { to favour giving advice on sleep } \\
\text { hygiene and prescribing a hypnotic } \\
\text { (Z-drugs favoured over } \\
\text { benzodiazepines). For anxiety, } \\
\text { referral to a psychologist/mental } \\
\text { health worker was favoured. }\end{array}$ & \multirow[t]{2}{*}{$\begin{array}{l}\text { Beliefs about } \\
\text { capabilities, } \\
\text { Environmental } \\
\text { context and } \\
\text { resources }\end{array}$} \\
\hline & & & & $\begin{array}{l}\text { Preference to reduce use of drugs } \\
\text { for insomnia but GPs felt } \\
\text { insufficient resources or alternative } \\
\text { management strategies were } \\
\text { available }\end{array}$ & \\
\hline \multirow[t]{3}{*}{$\begin{array}{l}\text { Hassed } \\
\text { et al. (2012) } \\
{[22]}\end{array}$} & \multirow[t]{3}{*}{$\begin{array}{l}\text { Australia, Melbourne } \\
\text { (metropolitan } \\
\text { sample) }\end{array}$} & \multirow[t]{3}{*}{15 General Practitioners } & \multirow[t]{3}{*}{$\begin{array}{l}\text { Focus groups }(n=7) \text { and } \\
\text { face-to-face interviews } \\
(n=8) \text {. DSKQ }\end{array}$} & $\begin{array}{l}\text { Scores from DSQK suggested gaps } \\
\text { in knowledge related to defining } \\
\text { the underlying cause and correct } \\
\text { treatment options. }\end{array}$ & \multirow[t]{3}{*}{$\begin{array}{l}\text { Knowledge, } \\
\text { Skills, } \\
\text { Environmental } \\
\text { context and } \\
\text { resources }\end{array}$} \\
\hline & & & & $\begin{array}{l}\text { Behavioural intervention were } \\
\text { viewed as preferable to prescribing } \\
\text { medication. }\end{array}$ & \\
\hline & & & & $\begin{array}{l}\text { Barriers to knowledge identified: } \\
\text { limited training, lack of resources, } \\
\text { patient expectation to receive a pill, } \\
\text { consultation time constraint. }\end{array}$ & \\
\hline
\end{tabular}


Table 1 Studies of general practitioners: measures and outcomes relating to insomnia (Continued)

\begin{tabular}{|c|c|c|c|c|c|}
\hline $\begin{array}{l}\text { Authors } \\
\text { (Year) [Ref] }\end{array}$ & $\begin{array}{l}\text { Country (community/ } \\
\text { cohort) }\end{array}$ & Study population & Measures & Main findings & TDF Domain(s) \\
\hline \multirow[t]{2}{*}{$\begin{array}{l}\text { Cheung } \\
\text { et al. (2014) } \\
\text { [43] }\end{array}$} & \multirow[t]{2}{*}{$\begin{array}{l}\text { Australia, Sydney } \\
\text { (metropolitan } \\
\text { sample) }\end{array}$} & \multirow[t]{2}{*}{ GPs $(n=8)$ Pharmacists $(n=14)$} & \multirow[t]{2}{*}{$\begin{array}{l}\text { Semi-structured } \\
\text { interview from a } \\
\text { convenience sample. } \\
\text { Data analysed using a } \\
\text { framework analysis }\end{array}$} & $\begin{array}{l}\text { Practitioners perceived an } \\
\text { overreliance on pharmacotherapy } \\
\text { and inadequate support to direct } \\
\text { patients to alternate pathways. }\end{array}$ & \multirow[t]{2}{*}{$\begin{array}{l}\text { Environmental } \\
\text { context and } \\
\text { resources }\end{array}$} \\
\hline & & & & $\begin{array}{l}\text { Patients often have a reliance or } \\
\text { expectation of a 'quick fix'. }\end{array}$ & \\
\hline \multirow[t]{3}{*}{$\begin{array}{l}\text { Conroy \& } \\
\text { Ebben } \\
(2015)[44]\end{array}$} & \multirow{3}{*}{$\begin{array}{l}\text { University of } \\
\text { Michigan Hospitals } \\
\text { and Weill Cornell } \\
\text { Medical College of } \\
\text { Cornell University. }\end{array}$} & \multirow[t]{3}{*}{ Physicians ( $n=239$ ) } & \multirow[t]{3}{*}{$\begin{array}{l}\text { Questionnaire -mailed } \\
\text { out }\end{array}$} & $\begin{array}{l}\text { Most physicians did not nominate } \\
\text { CBTi or a hypnotic as the most } \\
\text { effective treatment for insomnia. }\end{array}$ & \multirow[t]{3}{*}{$\begin{array}{l}\text { Knowledge, } \\
\text { Skills }\end{array}$} \\
\hline & & & & 1/3 recommended sleep hygiene. & \\
\hline & & & & $N=22$ felt $C B T i$ alone was effective. & \\
\hline \multirow[t]{4}{*}{$\begin{array}{l}\text { Davy et al., } \\
\text { (2015) [45] }\end{array}$} & \multirow{4}{*}{$\begin{array}{l}\text { Primary care in } \\
\text { Nottinghamshire and } \\
\text { Lincolnshire. }\end{array}$} & \multirow{4}{*}{$\begin{array}{l}\text { Health professionals }(n=23) \text {, } \\
\text { and patients with insomnia } \\
(n=28)\end{array}$} & \multirow[t]{4}{*}{$\begin{array}{l}\text { Focus groups, and } \\
\text { interviews }\end{array}$} & $\begin{array}{l}\text { Practitioners tended to focus on } \\
\text { sleep hygiene rather than CBTi. }\end{array}$ & \multirow{4}{*}{$\begin{array}{l}\text { Knowledge, } \\
\text { Skills, } \\
\text { Behavioural } \\
\text { Regulation }\end{array}$} \\
\hline & & & & $\begin{array}{l}\text { Some practitioners felt they } \\
\text { colluded with patients when } \\
\text { prescribing hypnotics. }\end{array}$ & \\
\hline & & & & $\begin{array}{l}\text { Patients often ignored sleep } \\
\text { hygiene advice, and sometimes } \\
\text { took hypnotics as not intended }\end{array}$ & \\
\hline & & & & $\begin{array}{l}\text { Both practitioners and patients } \\
\text { wanted more options and better } \\
\text { training }\end{array}$ & \\
\hline
\end{tabular}

DSKQ = Dartmouth Sleep Knowledge Questionnaire; GP = General Practitioner (equivalent to family practitioner in USA)

study is that people who typically seek help for insomnia do so because of other symptoms which reflect outcomes associated with insomnia, including impaired daytime functioning [36], psychological distress or physical discomfort [4] rather than insomnia itself. Indeed, Dyas et al. [9] reported that some patients felt that they had to convince a medical professional as to the seriousness of their insomnia-related symptoms, highlighting the barrier of Beliefs About Capability, which affects a patient's empowerment, confidence and self-esteem [31].

One barrier for patients identified in this study was Behavioural Regulation, reflecting that insomnia was more likely to be discussed only when symptoms were more complex, and/or daytime functioning was already impaired. For example, Morin and colleagues [4] reported that daytime fatigue, discomfort and psychological distress were factors likely to prompt individuals to seek treatment. Despite this, some patients who had reported suffering for long periods from insomnia felt a need to convince their health-care professional of their trouble sleeping [9], reinforcing the lack of awareness of the detrimental effects of insomnia on mood and performance by those seeking treatment.

We also identified that there is a knowledge barrier from the patient perspective, which likely represents a lack of awareness within the general public about the consequences of insomnia, and the available options regarding treatment. Given this identified barrier, targeting insomnia within the primary care environment is important from the perspective of both the practitioner and the patient. From the patient's viewpoint, those who sleep better experience less overall distress, and are more likely to play an active role in the management of their disease. From the practitioner's viewpoint, they are often the first point of call for any health or medical complaint and are in a position to provide the relevant support and resources [6].

There is often a patient expectation or Social norm barrier to receive a panacea "sleeping pill" in cases where insomnia has been a long-term problem, and also a reluctance from patients who have received a hypnotic drug to trial nonpharmacological approaches [42], despite hypnotics not being recommended as first-line treatment for insomnia [56]. This is supported by Australian data indicating high rates of sedative medication prescriptions to treat insomnia [57]. In addition, a recent survey of those in family practice and community pharmacists reported that practitioners perceive an overreliance on pharmacotherapy amongst insomnia patients [43]. One reason for this may be that patients have often tried self-help or relaxation methods prior to consulting a general practitioner and have lived with the condition for long periods prior to seeking help [9].

\section{Overcoming identified barriers}

In order to improve recognition and assessment of insomnia in family practice settings, a multifaceted approach addressing both clinician- and patient-factors is likely to be more effective than a single intervention [58, 59]. Given the barriers include the Environmental 
Table 2 Studies of patients: measures and outcomes relating to insomnia

\begin{tabular}{lllll}
\hline $\begin{array}{l}\text { Authors } \\
\text { (Year) }\end{array}$ & $\begin{array}{l}\text { Country } \\
\text { (town and } \\
\text { community) }\end{array}$ & Study population & Measures & Main findings \\
& & & TDF Domain(s) \\
\hline
\end{tabular}

\begin{tabular}{llllll}
\hline Kushida & United States & Primary care patients seen at the & Questionnaires (focused on sleep & $32.3 \%$ had insomnia (29.7\% of & Knowledge, \\
et al. & (Idaho, rural & clinic over a 1 year period (1997- & disordered symptoms for & men and 34.5\% of women). & Skills \\
(2000) & cohort) & 1998) $n=1249$, all 18+. & insomnia, RLS, OSA), ESS, SF-36 - & &
\end{tabular}

(2000) cohort) 1998) $n=1249$, all $18+$.

[18] (participation rate 60.1\% 1254/ 2087) insomnia, RLS, OSA), ESS, SF-36 daytime functioning (face-to-face or mail-out/ Interviews

Aikens \& Rouse (2005) [36]

\section{United States} Urban population)
$N=700$ consecutive attendees at primary care, screened for insomnia. 326 mailed a follow-up survey to which $n=180$ responded
Questionnaires assessing insomnia, sleep quality, and daytime consequences of sleepiness and fatigue (ISI, PSQI, ESS, DBAS, MFIS)
Morin Canada,

et al. Quebec

(2006) [4] Province.
2001 French speaking adults aged 18+. Mean age 44.7
Telephone survey with insomnia defined as per the DSM-IV and the ICD-10

\section{Bartlett Australia, et al. New South \\ (2008) [6] Wales, \\ (mixed urban-rural) \\ Postal survey of 10,000 people randomly selected from the electoral roll (5000 aged 18-24 and 5000 aged 25-64). 3300 responded. Direct contact with a random subset of non- responders ( $n=100)$ was under- taken (response rate of 49\%) by telephone.}

Postal survey and direct contact. Survey included AIS and ESS.

$\begin{array}{lll}\text { Bailes } & \text { Canada } & N=191 \text { older patients (aged } \\ \text { et al. } & \text { (Montreal, } & 50+\text { ) in primary care. } n=138 \\ \text { (2009) } & \text { city cohort) } & \begin{array}{l}\text { from } 2 \text { hospital-based sleep } \\ \text { clinics (new referrals aged } 18+\text { ). }\end{array} \\ \text { [27] } & & \end{array}$

Sleep Symptom Checklist- 21 items (insomnia, sleep disorders, daytime symptoms and psychological distress) they had discussed with their physician in the past year.

Subsequent PSG with primary care participants
$14.1 \%$ experienced insomnia on a nightly basis.

State that patients have limited access to sleep specialists and a lack of training for physicians

Of the 180 responders, $72 \%$ had probable insomnia. Those who had discussed it with their physician (52\% of those with probable insomnia) reported poorer overall health Those who were more educated, had >comorbid symptoms, lower TST or $>$ daytime dysfunction more likely to discuss

29.9\% reported insomnia symptoms.

$13 \%$ had consulted a healthcare professional about their insomnia.

$15 \%$ had used a herbal product, $11 \%$ a prescribed sleep medication, 3.84\% an OTC drug and $4.1 \%$ alcohol to manage insomnia.

Daytime fatigue, psychological distress and physical discomfort were symptoms prompting individuals to seek treatment.

Population weighted prevalence of insomnia $=33 \%$ and in $74.7 \%$ of these the complaint has been present for $>12$ months.

Behavioura regulation, Beliefs about consequences.

Population weighted prevalence of a visit to a doctor for insomnia $=11.1 \%$

Risk factors for insomnia were: older age, daytime sleepiness, short sleep duration $(<6.5 \mathrm{~h})$, reduced enthusiasm.

Self-medication for insomnia was common but often satisfaction with treatment was poor. For prescription drugs 39\% of users were satisfied compared with $16 \%$ for OTC drugs and 25\% for herbal products.

Primary care patients often have sleep symptoms they do not discuss, or discuss nonspecifically.

Those referred to the sleep clinic were more likely to have discussed sleep problems (also younger and more males)
Knowledge, Behavioural regulation, Beliefs about consequences.

Behavioural regulation, Beliefs about consequences. 
Table 2 Studies of patients: measures and outcomes relating to insomnia (Continued)

\begin{tabular}{|c|c|c|c|c|c|}
\hline $\begin{array}{l}\text { Authors } \\
\text { (Year) }\end{array}$ & $\begin{array}{l}\text { Country } \\
\text { (town and } \\
\text { community) }\end{array}$ & Study population & Measures & Main findings & TDF Domain(s) \\
\hline & & & & $\begin{array}{l}\text { Those who completed PSG more } \\
\text { likely to report sleep symptoms } \\
\text { compared with those who } \\
\text { completed questionnaire only. }\end{array}$ & \\
\hline \multirow[t]{5}{*}{$\begin{array}{l}\text { Dyas et al. } \\
(2010)[9]\end{array}$} & \multirow[t]{5}{*}{$\begin{array}{l}\text { UK } \\
\text { (Lincolnshire, } \\
\text { rural cohort }\end{array}$} & \multirow[t]{5}{*}{$\begin{array}{l}\text { Patients (who had sought help } \\
\text { for insomnia in the previous } 6 \\
\text { months) }\end{array}$} & \multirow[t]{5}{*}{$\begin{array}{l}\text { Focus groups/ semi-structured in- } \\
\text { terviews separate for patients } \\
(n=30,11 \mathrm{M}, 19 \mathrm{~F} \text {, aged } 25-70)\end{array}$} & $\begin{array}{l}\text { Patients felt a need to convince } \\
\text { professionals of their health } \\
\text { problems. }\end{array}$ & \multirow{5}{*}{$\begin{array}{l}\text { Beliefs about } \\
\text { capabilities, } \\
\text { Environmental } \\
\text { Context and } \\
\text { Resources }\end{array}$} \\
\hline & & & & $\begin{array}{l}\text { Patients often suffered for long } \\
\text { periods before seeking help, and } \\
\text { had tried self-help methods }\end{array}$ & \\
\hline & & & & $\begin{array}{l}\text { Patients recognised sleep } \\
\text { problems were linked to } \\
\text { detrimental outcomes. }\end{array}$ & \\
\hline & & & & $\begin{array}{l}\text { Clinicians noted multiple causes } \\
\text { of sleep problems }\end{array}$ & \\
\hline & & & & $\begin{array}{l}\text { Clinicians often focused on } \\
\text { underlying causes rather than } \\
\text { addressing treatment or } \\
\text { consequences of non-treatment. }\end{array}$ & \\
\hline \multirow{3}{*}{$\begin{array}{l}\text { Omvik } \\
\text { et al. } \\
(2010) \\
{[46]}\end{array}$} & \multirow[t]{3}{*}{ Norway } & \multirow[t]{3}{*}{$\begin{array}{l}\text { Epidemiological postal survey } \\
(n=5000) \text {. Mean age } 48.1\end{array}$} & $\begin{array}{l}\text { Sleep medication prevalence and } \\
\text { reasons for use questions }\end{array}$ & $\begin{array}{l}\text { Prevalence of sleep medication } \\
\text { use: Lifetime }=18.8 \% \text {, Current = } \\
7.9 \% \text { and Chronic }=4.2 \% .\end{array}$ & \multirow[t]{3}{*}{$\begin{array}{l}\text { Social } \\
\text { influences }\end{array}$} \\
\hline & & & \multirow[t]{2}{*}{$\begin{array}{l}\text { Bergen Insomnia Scale, Global } \\
\text { Sleep Assessment Questionnaire, } \\
\text { Structured Clinical Interview for } \\
\text { DSM., WHOqoL, SDS }\end{array}$} & $\begin{array}{l}\text { Sleep medication use associated } \\
\text { with low SES, older age, female } \\
\text { gender, frequent sleep and/or } \\
\text { mood disturbance. }\end{array}$ & \\
\hline & & & & $\begin{array}{l}\text { Among those who had ever used } \\
\text { a sleep medication, } 80.3 \% \text { would } \\
\text { prefer a non-drug treatment. }\end{array}$ & \\
\hline $\begin{array}{l}\text { Senthilvel } \\
\text { et al. } \\
\text { (2011) } \\
{[19]}\end{array}$ & $\begin{array}{l}\text { United States } \\
\text { (Cleveland } \\
\text { Ohio, urban } \\
\text { population) }\end{array}$ & $\begin{array}{l}\text { New adult patients aged } 18-65 \\
(n=101) 52 \% \text { female, mean } \\
\text { age }=38 \text { years }\end{array}$ & $\begin{array}{l}\text { CSHQ, Berlin, ESS, STOP, review of } \\
\text { GP records of the consultation }\end{array}$ & $\begin{array}{l}30 \% \text { of cases = possible insomnia, } \\
\text { but limited screening and sleep } \\
\text { history obtained during the } \\
\text { consult }\end{array}$ & $\begin{array}{l}\text { Environmental } \\
\text { Context and } \\
\text { resources }\end{array}$ \\
\hline \multirow{2}{*}{$\begin{array}{l}\text { Bjorvatn } \\
\text { et al. } \\
(2017) \\
{[15]}\end{array}$} & \multirow[t]{2}{*}{ Norway } & \multirow[t]{2}{*}{$\begin{array}{l}\text { Patients visiting their GP }(n= \\
\text { 1346), 35.9\% Male }\end{array}$} & \multirow{2}{*}{$\begin{array}{l}\text { BIS, Self-reported sleep problems } \\
\text { (1-item), insomnia (DSM-IV cri- } \\
\text { teria), hypnotic use }\end{array}$} & $\begin{array}{l}\text { BIS insomnia rate }=53.6 \% \text {, sleep } \\
\text { problems (single item) }=55.8 \% \text {. }\end{array}$ & \multirow[t]{2}{*}{$\begin{array}{l}\text { Knowledge, } \\
\text { Skills }\end{array}$} \\
\hline & & & & $\begin{array}{l}\text { Hypnotics used by } 16.2 \% \text { (daily } \\
\text { use was } 5.5 \% \text { ). }\end{array}$ & \\
\hline
\end{tabular}

RLS = Restless Legs Syndrome, OSA = Obstructive Sleep Apnoea, ESS = Epworth Sleepiness Scale, PSG = polysomnography, ISI = Insomnia Severity Index, Pittsburgh Sleep Quality Index, DBAS = Dysfunctional Beliefs About Sleep Scale, MFIS = Modified Fatigue Impact Scale, TST = Total Sleep Time, CSHQ = Cleveland Sleep Habits questionnaire, STOP = Rapid Screening Tool for OSA, AIS = Athens Insomnia Scale, WHOQoL = World Health Organization's quality of life assessment. SDS = Severity of Dependence Scale., DSM- Diagnostic and Statistical Manual, ICD-10 = International Classification of Diseases, 10th edition. DSKQ = Dartmouth Sleep Knowledge Questionnaire, BIS=Bergen Insomnia Scale, GP = General Practitioner (equivalent to family practitioner in USA)

Context specifically, suggested targets for improvement may include: increased awareness within the environment/clinic setting itself (e.g., chart reminders for physicians and infographic resources on the importance of discussing insomnia symptoms for patients); the provision of professional development resources and/or journal articles for physicians [41], increased education and training of those in primary care [17], and/or opportunities for brief interventions given the time barrier faced by those in family practice. For example, while > $80 \%$ of patients who had used a sleep medication would prefer a non-pharmacological treatment, many were not offered an alternative [46]. However, both a simplified sleep restriction intervention (which forms one part of CBTi) [60], and a shortened 5-session brief CBTi trial were found to increase both sleep quality and decrease insomnia symptoms during a 6-month trial [61].

A further avenue to overcome these barriers may include online competency training in sleep medicine which has proven effective for medical students [62], and could provide an avenue for continued training or professional development of physicians as part of continued professional development [63]. Indeed, a current trial is investigating whether use of i-Sleep, a guided online intervention will be feasible and effective for treating insomnia in primary care [64]. 
Table 3 Classification of insomnia: Important features ${ }^{a}$

\begin{tabular}{|c|c|c|c|}
\hline Features & Classification & Clinical note(s) & Further classification or notes \\
\hline \multicolumn{4}{|c|}{ Duration of symptoms } \\
\hline & Acute/Short-term (ICD-3) & Symptoms last $<3$ months & $\begin{array}{l}\text { Typically lasts } 1 \text { night to a few weeks. May result from illness or a } \\
\text { circadian rhythm disturbance such as jet-lag }\end{array}$ \\
\hline & $\begin{array}{l}\text { Chronic (ICD-3)/Insomnia } \\
\text { disorder (DSM-5) }\end{array}$ & Symptoms last $>3$ months & Usually trouble sleeping is reported $3+$ nights for $>3$ months \\
\hline \multicolumn{4}{|l|}{ Timing } \\
\hline & Onset & Falling asleep takes $>30$ min & \\
\hline & Maintenance & $\begin{array}{l}\text { Interruptions lasting more than } 30-45 \text { min } \\
\text { are experienced during the night }\end{array}$ & \\
\hline & Early termination & $\begin{array}{l}\text { Waking earlier than intended \& unable to } \\
\text { resume sleep }\end{array}$ & \\
\hline \multicolumn{4}{|l|}{ Severity } \\
\hline & Mild & Almost nightly complaint & little or no impairment on social or occupational functions \\
\hline & Moderate & Nightly complaint & Mild-moderate impairment on social/occupational functions \\
\hline & Severe & Nightly complaint & Severe impact on social/occupational functions \\
\hline
\end{tabular}

${ }^{\mathrm{a}}$ Further information on these issues is provided by $[1,2,49-52]$

\section{Limitations and future directions}

The TDF has been used extensively in health-related research [31], with an identified strength being its usefulness to researchers and practitioners from many disciplines. However, a limitation acknowledged in guidelines for the application of the TDF include that no formal guidance exists on how to apply the TDF. However, in the present article we present a strong rationale based on both literature and clinical acumen that the prevalence of insomnia symptoms encountered in family practice is high, yet as a disorder it remains largely under-recognised, and that the TDF provides an opportunity to synthesise knowledge in this area, allowing for relevant summaries of reported barriers and facilitators to promote progress and facilitate shared understanding. Future studies could examine the value of using narrative reviews along with frameworks such as the TDF to identify potential barriers and develop strategies to overcome these. Whilst undertaking specific qualitative studies provides in-depth understanding of the potential barriers, where there is substantial body of existing work that describes such barriers and facilitators it is a more responsible use of research to interrogate this data first.

Additionally, the application of the TDF does not allow for ranking or grading of studies based on their strengths and limitations. Future studies in this area should examine whether similar barriers and facilitators to other sleep disorders exist within family practice, and whether other allied health professionals (e.g., psychologists, social workers) encounter the same or different barriers to the recognition of insomnia to examine the generalisability of our findings.

\section{Conclusion}

Despite the high prevalence of insomnia symptoms encountered in family practice, as a disorder it remains largely under-recognised, underdiagnosed, and undertreated. The present article has identified barriers to the recognition of insomnia centred on the clinician and the patient using the TDF. By focussing on the diagnosis of insomnia, this article bridges a gap between the identification and management of insomnia within the family practice setting and provides a useful resource for clinicians.

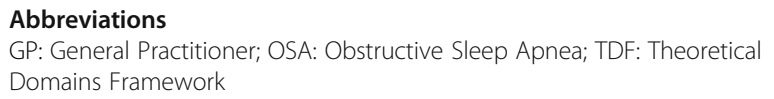

Authors' contributions

$\mathrm{RO}$ performed the literature search, screened abstracts and articles for inclusion and classified barriers/facilitators using the TDF. SC provided expert knowledge of family practice environments and themes. AY provided expert knowledge of insomnia and sleep assessments, and assisted in the development of the important feature table DL oversaw the project, and provided expertise into barriers faced by physicians in the health system. All authors contributed tp the manuscript, and approved the final submitted version.

\section{Funding}

Rowan Ogeil was supported by a Peter Doherty Fellowship from the NHMRC (Australia): GNT1071725.

\section{Availability of data and materials}

Data sharing is not applicable to this article as no datasets were generated or analysed during the current study.

Ethics approval and consent to participate Not applicable. 


\section{Consent for publication}

Not applicable.

\section{Competing interests}

The authors declare that they have no competing interests with respect to the present manuscript. DL has previously received speaking honoraria from AstraZeneca, Camurus, Indivior, Janssen, Servier, Shire and Lundbeck and has provided consultancy advice to Lundbeck and Indivior.

\section{Author details}

${ }^{1}$ Eastern Health Clinical School and Monash Addiction Research Centre, Monash University, Melbourne, Australia. ${ }^{2}$ Turning Point, Eastern Health, 110 Church St, Richmond, Victoria 3121, Australia. ${ }^{3}$ Department of General Practice, School of Primary and Allied Health Care, Monash University, Melbourne, Australia. ${ }^{4}$ Eastern Clinical Research Unit, Monash University, and Eastern Health, Melbourne, Australia.

\section{Received: 20 November 2018 Accepted: 16 December 2019}

\section{Published online: 04 January 2020}

\section{References}

1. American Academy of Sleep Medicine, editor. International classification of sleep disorders. 3rd ed. Darien: American Academy of Sleep Medicine; 2014.

2. American Psychiatric Association. Diagnostic and statistical manual of mental disorders. 5th ed. Arlington: American Psychiatric Publishing; 2013.

3. Wilson SJ, Nutt DJ, Alford C, Argyropoulos SV, Baldwin DS, Bateson AN, et al. British Association for Psychopharmacology consensus statement on evidence-based treatment of insomnia, parasomnias and circadian rhythm disorders: an update. J Psychopharmacol. 2019;33:8.

4. Morin CM, LeBlanc M, Daley M, Gregoire JP, Merette C. Epidemiology of insomnia: prevalence, self-help treatments, consultations, and determinants of help-seeking behaviors. Sleep Med. 2006;7:123-30

5. Riemann D, Bagilioni C, Bassetti C, Bjorvatn B, Dolenc Groselj L, et al. European guideline for the diagnosis and treatment of insomnia. J Sleep Res. 2017;26:675-700.

6. Bartlett DJ, Marshall NS, Williams A, Grunstein RR. Predictors of primary medical care consultation for sleep disorders. Sleep Med. 2008:9:857-64.

7. Ohayon MM. Epidemiological overview of sleep disorders in the general population. Sleep Med Res. 2011;2:1-9.

8. Saper CB, Scammell TE. Emerging therapeutics in sleep. Ann Neurol. 2013; 74:435-40.

9. Dyas JV, Apekey TA, Tilling M, Ørner R, Middleton $H$, Siriwardena AN Patients' and clinicians' experiences of consultations in primary care for sleep problems and insomnia: a focus group study. Br J Gen Pract 60:e180-200.

10. Hillman DR, Murphy AS, Pezzullo L. The economic cost of sleep disorders. Sleep. 2006;29:299-305.

11. Ozminkowski RJ, Wang S, Walsh JK. The direct and indirect costs of untreated insomnia in adults in the United States. Sleep. 2007;30:263-73.

12. Kessler RC, Berglund PA, Coulouvrat C, Hajak G, Roth T, Shahly V, Shillington AC, Stephenson JJ, Walsh JK. Insomnia and the performance of US Workers: results from the America insomnia survey. Sleep. 2011;34:1161-71.

13. Mansfield DR, Hillman DR, Antic NA, McEvoy RD, Rajaratnam SMW. Sleep loss and sleep disorders: shedding light on common but under-recognised individual and community problems. Med J Aust. 2013:199:S5-6.

14. Arroll B, Fernando A, Falloon K, Goodyear-Smith F, Samaranayake C, Warman G. Prevalence of causes of insomnia in primary care: a crosssectional study. Br J Gen Pract. 2012;62:e99-103.

15. Bjorvatn B, Meland E, Flo E, Mildestvedt T. High prevalence of insomnia and hypnotic use in patients visiting their general practitioner. Fam Pract. 2017:34:20-4.

16. Cunnington D. Non-benzodiazepine hypnotics: do they work for insomnia? BMJ. 2013;346:e8699.

17. Dement W, Netzer N. Primary care: is it the setting to address sleep disorders? Sleep Breath. 2000;4:1-9

18. Kushida CA, Nichols DA, Simon RD, Young T, Grauke JH, Britzmann JB, Hyde PR, Dement WC. Symptom-based prevalence of sleep disorders in an adult primary care population. Sleep Breath. 2000:4:9-14

19. Senthilvel E, Auckley D, Dasarathy J. Evaluation of sleep disorders in the primary care setting: history taking compared to questionnaires. J Clin Sleep Med. 2011;7:41-8
20. Ramakrishnan K. Treatment options for insomnia. S Af Fam Pract. 2007:49:34-41.

21. Cunnington D, Junge MF, Fernando AT. Insomnia: prevalence, consequences and effective treatment. Med J Aust. 2013;199:S36-40.

22. Hassed C, Antoniades J, Jones K, Rajaratnam S, Kiropolous L. An examination of Australian general practitioners' knowledge, attitudes and practices in relation to sleep disorders. Malays Fam Phys. 2012;7:16-23.

23. Cranney M, Warren E, Barton S, Gardner K, Walley T. Why do GPs not implement evidence-based guidelines? A descriptive study. Fam Pract. 2001; 18:359-63.

24. Zwolsman S, tePas E, Hooft L, Wieringa-deWaard M, van Dijk N. Barriers to GPs' use of evidence-based medicine: a systematic review. Br J Clin Pract. 2012:62:511-21.

25. Hisham R, Ng CJ, Liew M, Hamzah N, Ho GJ. Why is there variation in the practice of evidence-based medicine in primary care? A qualitative study. BMJ-Open. 2016;6. https://doi.org/10.1136/bmjopen-2015-010565.

26. Rosen RC, Zozula R, Jahn EG, Carson JL. Low rates of recognition of sleep disorders in primary care: comparison of a community-based versus clinical academic setting. Sleep Med. 2001;2:47-55.

27. Bailes S, Baltzan M, Rizzo D, Fichten CS, Grad R, Wolkove N, Creti L, Amsel R, Libman E. Sleep disorder symptoms are common and unspoken in Canadian general practice. Fam Pract. 2009;26:294-300.

28. Miles A, Asbridge JE. The European Society for Person Centered Healthcare (ESPCH) - raising the bar of health care quality in the Century of the Patient. J Eval Clin Pract. 2014;20:729-33.

29. Birken AA, Powell BJ, Shea C, Haines ER, Kirk MA, Leeman J, et al. Criteria for selecting implementation science theories and frameworks: results from an international survey. Implement Sci. 2017;12:124

30. Glanz K, Bishop DB. The role of behavioral science theory in development and implementation of public health interventions. Annu Rev Public Health. 2010;31:399-418.

31. Atkins L, Francis J, Islam R, O'Connor D, Patey A, Ivers $\mathrm{N}$, et al. A guide to using the theoretical domains framework of behaviour change to investigate implementation problems. Implement Sci. 2017:12:77.

32. Beenstock J, Sniehotta FF, White M, Bell R, Milne EMG, Araujo-Soares V. What helps and hinders midwives in engaging with pregnant women about stopping smoking? A cross-sectional survey of perceived implementation difficulties among midwives in the North East of England. Implement Sci. 2012;7:36

33. Michie $\mathrm{S}$, Johnston M, Abraham C, Lawton R, Parker D, Walker A. Making psychological theory useful for implementing evidence based practice: a consensus approach. BMJ Qual Saf. 2005;14:26-33.

34. Yamada J, Potestion ML, Cave AJ, Sharpe H, Johnson DW, Patey AM, Presseau J, Grimshaw JM. Using the theoretical domains framework to identify barriers and enablers to pediatric asthma management in primary care settings. J Asthma. 2017;20:1-14

35. Ferrari R. Writing narrative style literature reviews. Med Writ. 2015;24:230-5.

36. Aikens JE, Rouse ME. Help-seeking for insomnia among adult patients in primary care. J Am B Fam Pract. 2005;18:257-61.

37. Orr WC, Stahl ML, Dement WC, Reddington D. Physician education in sleep disorders. J Med Educ. 1980:55:367-9.

38. Hohagen F, Rink K, Käppler C, Schramm E, Riemann D, Weyerer S, Berger M. Prevalence and treatment of insomnia in general practice. A longitudinal study. Eur Arch Psychiatry Clin Neurosci. 1993;242(6):329-36.

39. Hohagen F, Käppler C, Schramm E, Rink K, Weyerer S, Riemann D, Berger M. Prevalence of insomnia in elderly general practice attenders and the current treatment modalities. Acta Psychiatr Scand. 1994;90:102-8.

40. Haponik EF, Frye AW, Richards B, Wymer A, Hinds A, Pearce K, McCall V, Konen J. Sleep history is neglected diagnostic information. Challenges for primary care physicians. J Gen Intern Med. 1996:11:759-61.

41. Papp KK, Penrod CE, Strohl KP. Knowledge and attitudes of primary care physicians toward sleep and sleep disorders. Sleep Breath. 2002;6:103-9.

42. Siriwardena AN, Apekey T, Tilling M, Dyas JV, Middleton H, Ørner R. General practitioners' preferences for managing insomnia and opportunities for reducing hypnotic prescribing. J Eval Clin Pract. 2010;16:731-7.

43. Cheung JM, Atternas K, Melchior M, Marshall NS, Fois RA, Saini B. Primary health care practitioner perspectives on the management of insomnia: a pilot study. Aust J Prim Health. 2014;20:103-12.

44. Conroy DA, Ebden MR. Referral practices for cognitive behavioral therapy for insomnia: a survey study. Behav Neurol. 2015. https://doi.org/10.1155/2015/819402. 
45. Davy Z, Middlemass J, Siriwardena AN. Patients' and clinicians' experiences and perceptions of the primary care management of insomnia: qualitative study. Health Expect. 2013;18:1371-83.

46. Omvik S, Pallesen S, Bjorvatn B, Sivertsen B, Havik OE, Nordhus IH. Patient characteristics and predictors of sleep medication use. Int J Clin Psychopharmacol. 2010;25:91-100.

47. Mindell JA, Bartle A, Wahab NA, Ahn Y, Ramamurthy MB, Huong HT, Kohyama J, Ruangdaraganon N, Sekartini R, Teng A, Goh DY. Sleep education in medical school curriculum: a glimpse across countries. Sleep Med. 2011;12:928-31.

48. Lu B, Budhiraja R, Parthasarathy S. Sedating medications and undiagnosed obstructive sleep apnea: physician determinants and patient consequences. J Clin Sleep Med. 2005;1:367-71.

49. Morin CM, Benca R. Chronic insomnia. Lancet. 2012;379:1129-41.

50. Rosenberg RP. Sleep maintenance insomnia: strengths and weaknesses of current pharmacologic therapies. Ann Clin Psychiatry. 2006;18:49-56.

51. Duong M-T, Passarella S. Diagnosis and treatment of insomnia. Am J Health Syst Pharm. 2008;65:927.

52. Grima NA, Bei B, Mansfield D. Insomnia theory and assessment. Aust J Gen Pract. 2019;48(4):193.

53. Rosen R, Zozula R. Education and training in the field of sleep medicine. Curr Opin Pulm Med. 2000;6:512-8.

54. Chung K-F, Lee C-T, Yeung W-F, Chan M-S, Chung E, Lin W-L. Sleep hygiene education as a treatment of insomnia: a systematic review and metaanalysis. Fam Pract. 2017. https://doi.org/10.1093/fampra/cm×122.

55. Holbrook AM, Crowther R, Lotter A, Cheng C, King D. The diagnosis and management of insomnia in clinical practice: a practical evidence-based approach. CMAJ. 2000;162:216-20.

56. Psychotropic Expert Group. Therapeutic guidelines: psychotropics. Melbourne: Therapeutic Guidelines Limited; 2013.

57. Charles J, Harrison C, Britt H. Insomnia. Aust Fam Physician. 2009;38:283.

58. Oxman AD, Thomson MA, Davis DA, Haynes RB. No magic bullets: a systematic review of 102 trials of interventions to improve professional practice. CMAJ. 1995;15(153):1423-31.

59. Wensing M, Van der Weijden T, Grol R. Implementing guidelines an innovations in general practice: which interventions are effective? $\mathrm{Br} J$ Gen Pract. 1998:48:991-7.

60. Ashworth DK, Sletten TL, Junge M, Simpson K, Clarke D, Cunnington D, Rajaratnam SMW. A randomized controlled trial of cognitive behavioral therapy for insomnia: an effective treatment for comorbid insomnia and depression. J Couns Psychol. 2015;62:115-23.

61. Falloon K, Elley CR, Fernando A, Lee AC, Arroll B. Simplified sleep restriction for insomnia in general practice: a randomised controlled trial. $\mathrm{Br} J \mathrm{Gen}$ Pract. 2015;65:e508-15.

62. Bandla H, Franco RA, Simpson D, Brennan K, McKanry J, Bragg D. Assessing learning outcomes and cost effectiveness of an online sleep curriculum for medical students. J Clin Sleep Med. 2012;8:439-43.

63. Zozula R, Rosen RC, Jahn EG, Engel SH. Recognition of sleep disorders in a community-based setting following an educational intervention. Sleep Med. 2005;6:55-61.

64. Van der Zweerde T, Lancee J, Slottje P, Bosmans J, van Someren E, Reynolds C, Cuipers P, van Straten A. Cost-effectiveness of i-Sleep, a guided online CBT intervention, for patients with insomnia in general practice: protocol of a pragmatic randomized controlled trial. BMC Psychiatry. 2016;16:85.

\section{Publisher's Note}

Springer Nature remains neutral with regard to jurisdictional claims in published maps and institutional affiliations.

Ready to submit your research? Choose BMC and benefit from:

- fast, convenient online submission

- thorough peer review by experienced researchers in your field

- rapid publication on acceptance

- support for research data, including large and complex data types

- gold Open Access which fosters wider collaboration and increased citations

- maximum visibility for your research: over $100 \mathrm{M}$ website views per year

At BMC, research is always in progress.

Learn more biomedcentral.com/submissions 